\title{
Exploring Self-Management Practices Among Patients with Diabetes in Government Hospitals in the Upper West Region of Ghana
}

\author{
Stephen Kpekura ${ }^{1}$, Jerry Paul Kukye-Ayiri Ninnoni ${ }^{2}$, Samuel Victor Nuvor ${ }^{3}$ \\ ${ }^{1}$ Department of Adult Health, University of Cape Coast, Cape Coast, Ghana \\ ${ }^{2}$ Department of Mental Health, University of Cape Coast, Cape Coast, Ghana \\ ${ }^{3}$ Department of Immunology and Microbiology, University of Cape Coast, Cape Coast, Ghana \\ Email address: \\ kpekurastephen@yahoo.com (S. Kpekura), jerry.ninnoni@ucc.edu.gh (J. P. Kukye-Ayiri N.), s.v.nuvor@uccsms.edu.gh (S. V. Nuvor) \\ ${ }^{*}$ Corresponding author
}

\section{To cite this article:}

Stephen Kpekura, Jerry Paul Kukye-Ayiri Ninnoni, Samuel Victor Nuvor. Exploring Self-Management Practices Among Patients with Diabetes in Government Hospitals in the Upper West Region of Ghana. International Journal of Diabetes and Endocrinology.

Vol. 3, No. 3, 2018, pp. 35-40. doi: 10.11648/j.ijde.20180303.11

Received: September 17, 2018; Accepted: September 28, 2018; Published: October 25, 2018

\begin{abstract}
Diabetes mellitus is a chronic progressive metabolic disorder characterized by hyperglycaemia mainly due to absolute or relative deficiency of insulin hormone. The study aimed at exploring the level of self-management practices among diabetes patients receiving care in public hospitals in the Upper West Region of Ghana. The research was a cross-sectional survey adopting stratified sampling technique to select 201 respondents. A questionnaire was used in the study for data collection with a reliability coefficient of 0.8 . The data was analyzed using the SPSS version 21 . Adherence to proper selfmanagement practices was high with a mean percentage of $64.7 \%$. Demographic factors of diabetes patients did not have any effect on their Self-Management Practices $(p>0.05)$. There were differences in Self-Management practices among group of diabetes patients receiving care at different hospitals $(\mathrm{p}<0.05)$. In conclusion, most diabetes patients in the Upper West Region adhered correctly to self-management practices. However, they needed to improve upon the management on monitoring of blood sugar level and foot care. There was a difference in self-management practices of diabetes patients who received care at Wa and Lawra. It was also found that sex, gender, district of location, occupation, and income among others did not have influence on self-management practice.
\end{abstract}

Keywords: Diabetes, Patients, Self-Management, Practices, Hospitals

\section{Introduction}

Diabetes is characterized by a disorder in metabolism of carbohydrate and subsequent derangement of fat and protein metabolism [1]. Furthermore, disturbance in production and action of insulin, and a hormone secreted by the islets of Langerhans in the pancreas were also implicated in the disease [1]. In addition to insulin, aging, over weight and several other hormones affect blood glucose level thereby preventing glucose from entering the cells [2]. This leads to hyperglycemia, which may result in acute and chronic complications such as diabetic keto-acidosis, coronary artery disease, cerebrovascular disease, kidney and eye diseases, disorders of the nerves and others [3].
A Global status report on Non-Communicable Diseases (NCDs), postulated that NCDs including type 2 diabetes mellitus (T2DM) will become the leading cause of death on the African continent by 2030 [4]. There has been a drastic increase in the prevalence of type 2 diabetes over the past decades due to the perpetual increase in obesity [5].

At least 171 million people worldwide suffer from diabetes and it is more prevalent in developed countries. This increase in incidence of diabetes in developing countries follows the trend of urbanization and lifestyle changes including perhaps and most importantly a "Western - Style" diet [6].

Egypt had been estimated to be the 9th country in the 
prevalence of diabetes in the world [7]. Recent changes in physical activity and dietary patterns have promoted the development of diabetes and if different preventive and control activities are not adopted, by the year 2025, more than 9 million Egyptians (13\% of the population above 20 years old) will have diabetes [7]. In Nigeria though no estimate of the individuals suffering from diabetes has been made, in a recent screening exercise carried out in Warri and Sapele involving 787 people, 65\% were diabetic and hypertensive [8].

Evidence of the dramatic costs of treating diabetes and its complications were found in the CODE-2 study which reported the total direct costs of type 2 diabetes (T2D) to be 29 billion Euros in 1998 [9]. The study revealed the lack of specific programs to address it and attributed the rise in diabetes to obesity, sedentary life style and unhealthy diets.

Report concerning Ghana showed that 440,000 adult populations in Ghana within the ages of 20-79 years had diabetes with a national prevalence of $3.35 \%$ ( 1 in every 30 adults). Eight thousand, five hundred and twenty eight deaths in Ghana were diabetes related, of which $72.4 \%$ were diabetes patients under 60 years [10]. NCDs were estimated to account for $43 \%$ of total deaths in Ghana of which diabetes contributed $2 \%$. Diabetes is also said to be among the top 4 causes of mortality due to non-communicable diseases [11].

It was indicated in the Ghana Health Sector 2013 Program of Work that there had been an increased in the incidence of non-communicable diseases in the country [12]. Hence a call was made to all and sundry to adopt a healthy lifestyle and routine check-ups. These have created much awareness of Diabetes as a condition in some communities especially in the Northern part of Ghana [13]. The document also provided core programs to be undertaken to scale up and improve management of diabetes and hypertension [12].

Therefore, the purpose of the study was to explore the selfmanagement practices among diabetes patients and to explore the differences in management among patients receiving care at the chosen hospitals.

\section{Methodology}

\subsection{Research Design}

A cross-sectional survey was employed to find out from diabetes patients in the selected hospitals how they were involved in self-management practices recommended for diabetes patients.

\subsection{Study Setting}

This study was conducted in the Upper West Region; at the Wa Regional Hospital, Lawra District Hospital and Nandom District Hospital. These institutions were selected because they were the hospitals that run diabetic clinics at the time of commencement of the research.

\subsection{Population}

Target population for the study was Diabetes Patients who attended diabetic clinics in the various hospitals in the Upper West Region.

\subsection{Sample and Sampling Procedure}

This study included people with type 2 diabetes in the three selected government hospitals in the region. The total number of diabetes type 2 patients who attended clinic in these hospitals was estimated to be 404 by the end of March 2016. The researcher used the sample size calculation with the proportionate sample allocation to the three hospitals [14]. This calculation translated into sample size of Wa Regional Hospital to be 151, that of Lawra District Hospital to be 22 and finally 28 for Nandom District Hospital. Total was 201 .

\subsection{Data Collection}

Data was collected by using a questionnaire. Ample time was given to the respondents to study the pattern of the instruments and to answer appropriately without being rushed. There was an interpreter in a dialect of the respondent to assist filling the questionnaire for patients who could not read and write.

\subsection{Data Analysis}

The collected data was analyzed by using the Statistical Package for the Social Sciences (SPSS) Version 21 software. Descriptive and inferential statistics techniques were employed in the study by using frequency distribution, Regression and ANOVA.

\section{Results}

\subsection{Demographic Characteristics}

From Table 1, majority of the respondents were females $(138,69.7 \%)$ and $103,(51.2 \%)$ of them were between ages 40 and 59 years. The males were $63(31.3 \%)$. Again, majority of the study respondents $(153,76.1 \%)$ were married as well as coming from Wa district (151, 75.2\%). Twenty eight people (13.9\%) were from Nandom district and lastly, 22 $(10.0 \%)$ from Lawra district respectively. The study revealed that $62.7 \%$ of the respondents had at least primary education as compared to $75(37.3 \%)$ who had no formal education. Greater proportion $(107,53.2 \%)$ of respondents were selfemployed and $25(12.4 \%)$ unemployed. Most of the respondents were not found in the government sector probably because they did not pursue higher education. Majority $(110,54.7 \%)$ of respondents involved in the study followed the Islam faith. About 75 (37.3\%) were Christians and lastly, $16(8.0 \%)$ were Traditionalist. It could also be seen that the dominant proportion $(50.8 \%)$ of the respondents contracted diabetes five or more years ago.

For earnings from work, majority of the participants (68, $33.9 \%$ ) were earning salaries less than GhC 200.OO. Twelve point four percent of the study respondents did not earn salaries. This could be as a result of unemployment since the 
same percentage indicated they were not employed.

Table 1. Socio-demographic characteristic.

\begin{tabular}{|c|c|c|}
\hline Age Range of respondents & Frequency & Percent (\%) \\
\hline $20-39$ years & 21 & 10.5 \\
\hline Years & 103 & 51.2 \\
\hline Above 59 years & 77 & 38.3 \\
\hline Total & 201 & 100.0 \\
\hline \multicolumn{3}{|l|}{ Sex of respondents } \\
\hline Male & 63 & 31.3 \\
\hline Female & 138 & 69.7 \\
\hline Total & 201 & 100.0 \\
\hline \multicolumn{3}{|l|}{ Marital Status } \\
\hline Never married & 8 & 4.0 \\
\hline Married & 153 & 76.1 \\
\hline Divorced & 6 & 3.0 \\
\hline Separated & 4 & 2.0 \\
\hline Widowed & 29 & 14.4 \\
\hline Cohabitating & 1 & .5 \\
\hline Total & 201 & 100.0 \\
\hline \multicolumn{3}{|l|}{ District } \\
\hline Wa & 151 & 75.2 \\
\hline Lawra & 22 & 10.9 \\
\hline Nandom & 28 & 13.9 \\
\hline Total & 201 & 100.0 \\
\hline \multicolumn{3}{|l|}{ Education level } \\
\hline No formal education & 75 & 37.3 \\
\hline Primary school & 43 & 21.4 \\
\hline Secondary school & 41 & 20.4 \\
\hline Training college/Poly & 17 & 8.5 \\
\hline University & 25 & 12.4 \\
\hline Total & 201 & 100.0 \\
\hline \multicolumn{3}{|l|}{ Occupation } \\
\hline Government employee & 63 & 31.3 \\
\hline Self-employed & 107 & 53.2 \\
\hline Private sector workers & 6 & 3.1 \\
\hline Unemployed & 25 & 12.4 \\
\hline Total & 201 & 100.0 \\
\hline \multicolumn{3}{|l|}{ Religion } \\
\hline Christian & 75 & 37.3 \\
\hline Islam & 110 & 54.7 \\
\hline Traditional & 16 & 8.0 \\
\hline Total & 201 & 100.0 \\
\hline \multicolumn{3}{|l|}{ Duration } \\
\hline Less than one year & 20 & 10.0 \\
\hline One year ago & 22 & 10.9 \\
\hline Two years ago & 37 & 18.4 \\
\hline Three years ago & 24 & 11.9 \\
\hline Four years ago & 16 & 8.0 \\
\hline Five years ago & 17 & 18.5 \\
\hline More than five years ago & 65 & 32.3 \\
\hline Total & 201 & 100.0 \\
\hline \multicolumn{3}{|l|}{ Income level } \\
\hline Less than $\mathrm{GHC} 200$ & 68 & 33.9 \\
\hline GHC200-400 & 34 & 16.9 \\
\hline GHC500-700 & 16 & 8.0 \\
\hline GHC800-1000 & 31 & 15.4 \\
\hline GHC1000-3000 & 27 & 13.4 \\
\hline Not applicable & 25 & 12.4 \\
\hline Total & 201 & 100.0 \\
\hline
\end{tabular}

\subsection{Self-Management Practices of Diabetes Patients}

Table 2. Self-management practices.

\begin{tabular}{|c|c|c|c|c|}
\hline \multirow[t]{2}{*}{ Medication } & \multicolumn{2}{|c|}{$\begin{array}{l}\text { Does not } \\
\text { apply to me }\end{array}$} & \multicolumn{2}{|c|}{$\begin{array}{l}\text { Applies to } \\
\text { me }\end{array}$} \\
\hline & Freq & $(\%)$ & freq & $(\%)$ \\
\hline I adhere correctly to my medication regimen & 13 & 6 & 188 & 94 \\
\hline $\begin{array}{l}\text { I never missed a single dose of medication in } \\
\text { the past week }\end{array}$ & 22 & 11 & 179 & 89 \\
\hline I am taking my diabetic drugs for life & 22 & 11 & 139 & 89 \\
\hline $\begin{array}{l}\text { Instructions about my drugs are followed } \\
\text { strictly }\end{array}$ & 23 & 11 & 178 & 89 \\
\hline $\begin{array}{l}\text { I don't stop taking my medication when I feel } \\
\text { better }\end{array}$ & 24 & 12 & 177 & 88 \\
\hline Mean percentage & & 10.2 & & 89.8 \\
\hline Nutrition & & & & \\
\hline I eat less/no white bread (ordinary bread) & 42 & 21 & 159 & 79 \\
\hline $\begin{array}{l}\text { I eat less fatty foods, including bacon, "meat"; } \\
\text { use less fat }\end{array}$ & 30 & 15 & 170 & 85 \\
\hline $\begin{array}{l}\text { I reduce intake of sugar and sweets (cookies, } \\
\text { cakes) }\end{array}$ & 27 & 13 & 174 & 87 \\
\hline I eat more frequently, but smaller portions & 47 & 13 & 154 & 87 \\
\hline I eat more fruits and vegetables & 27 & 13 & 174 & 87 \\
\hline Drink more soup & 39 & 19 & 162 & 81 \\
\hline I eat on a schedule & 53 & 26 & 148 & 74 \\
\hline $\begin{array}{l}\text { I have never eaten food forbidden by diabetes } \\
\text { patients }\end{array}$ & 60 & 30 & 141 & 70 \\
\hline I do not drink alcoholic beverages & 60 & 30 & 141 & 70 \\
\hline Mean percentage & & 20 & & 80 \\
\hline \multicolumn{5}{|l|}{ Monitoring of blood sugar } \\
\hline I monitor my own blood glucose level & 137 & 69 & 62 & 31 \\
\hline I have a glucose meter myself & 143 & 71 & 58 & 29 \\
\hline $\begin{array}{l}\text { I monitor my blood sugar level more than once } \\
\text { every week }\end{array}$ & 151 & 75 & 50 & 25 \\
\hline $\begin{array}{l}\text { I do measure my blood glucose level before } \\
\text { and after every planned activity }\end{array}$ & 129 & 64 & 72 & 36 \\
\hline Mean percentage & & 69.8 & & 30.2 \\
\hline \multicolumn{5}{|l|}{ Foot care } \\
\hline I regularly examine my feet for abnormalities & 78 & 39 & 123 & 61 \\
\hline $\begin{array}{l}\text { I do not add detergent to the water I use to } \\
\text { wash my feet }\end{array}$ & 81 & 40 & 120 & 60 \\
\hline I dry my feet thoroughly following washing & 73 & 36 & 128 & 64 \\
\hline I lubricate my feet following washing & 92 & 46 & 109 & 54 \\
\hline I use blunt instrument to clean under my nail & 87 & 43 & 114 & 57 \\
\hline I cut my nails by the help of others & 126 & 63 & 75 & 37 \\
\hline $\begin{array}{l}\text { I wear a foot wear that is closed to protect my } \\
\text { feet }\end{array}$ & 122 & 61 & 79 & 39 \\
\hline I make sure I do not walk barefooted & 82 & 41 & 119 & 59 \\
\hline $\begin{array}{l}\text { The socks I use do not have rubber material in } \\
\text { them }\end{array}$ & 115 & 57 & 86 & 43 \\
\hline $\begin{array}{l}\text { I change my socks every day/wear clean socks } \\
\text { every day }\end{array}$ & 112 & 56 & 89 & 44 \\
\hline Mean percentage & & 48.2 & & 51.8 \\
\hline \multicolumn{5}{|l|}{ Exercise } \\
\hline Exercise is a priority to me & 52 & 26 & 149 & 74 \\
\hline Walking is my preferred exercise & 44 & 22 & 157 & 78 \\
\hline I exercise every day & 63 & 31 & 138 & 69 \\
\hline I exercise at least twice a week & 60 & 30 & 141 & 70 \\
\hline $\begin{array}{l}\text { I exercise } 20-30 \text { minutes per day for at least } \\
\text { three days in a week }\end{array}$ & 67 & 33 & 134 & 67 \\
\hline Mean percentage & & 28.4 & & 71.6 \\
\hline Over all mean percentage & & 35.3 & & 64.7 \\
\hline
\end{tabular}


The self-management of diabetes was assessed on the following sub scale: medication, nutrition, monitoring of blood sugar, foot care and exercise. Respondents were to indicate 'does not apply to me' or 'it applies to me' to show how they practiced their self-management activities.

From table 2, the highest score on medication subscales was $94 \%$ which indicated that participants adhered correctly to their medication regimen. Eighty nine percent of the participants indicated they never missed their medications, they followed their drugs instructions correctly and that they were taking their drugs for life. Eighty eight percent of the participants asserted they never stopped taking their medications even when they felt better. Averagely, $89.8 \%$ of the respondents adhered correctly to their medications.

Scores on nutrition subscales indicated that $87 \%$ of the participants indicated the following; reduced intake of sugar, ate smaller quantities at frequent intervals and ate more fruits and vegetables. Eighty five percent ate less fatty foods and $81 \%$ took more soup. Comparatively, the lowest score $(70 \%)$ indicated they did not drink alcoholic beverages. On the average, $80 \%$ of the study participants adhered correctly to nutrition practices.

On the monitoring of blood sugar level, lower scores were obtained. Thirty one percent of the participants monitored their blood glucose level on their own. Twenty nine percent possessed a glucose meter. Twenty five percent monitored their blood glucose level more than ones weekly whiles $36 \%$ monitored before and after every planned activity. Averagely, $30 \%$ of the participants adhered to correct practices of blood glucose monitoring.

On foot care, $64 \%$ of the study participants which represented the highest score indicated that participants dried their feet after washing. Sixty one percent examined their feet regularly for abnormalities. The scores on some of the sub scales were below average. For instance, $37 \%$ of the participants cutting their nails by the help of others, 39\% wearing closed foot wear, $43 \%$ using socks without rubber material and $44 \%$ wearing clean socks. On the whole, barely above average $(51.8 \%)$ of the participants adhered to correct foot care practices.

On exercise subscales, participants scored higher percentages. Seventy four percent said exercise was a priority, $78 \%$ preferred walking as exercise, $69 \%$ exercised every day, $70 \%$ exercised at least twice weekly and finally $67 \%$ exercised 20-30 minutes per day for at least three days in a week.

\subsection{Effect of Demographic Factors on Self-Management Practices}

The study sought to find out from respondents whether demographic factors affected self-management practices. The regression analysis was used to test the effect. From Table 3, the demographic factors which included age, sex, marital status, education, occupation, religious affiliation, duration of diabetes and monthly income did not affect self-management practices $(\mathrm{p}>0.05)$.
Table 3. Effects of Demographic factors on Self-Management Practices.

\begin{tabular}{llllll}
\hline Model & \multicolumn{2}{l}{$\begin{array}{l}\text { Unstandardized } \\
\text { Coefficients }\end{array}$} & $\begin{array}{l}\text { Standardized } \\
\text { Coefficient }\end{array}$ & T & P value \\
\hline & B & Std. Error & Beta & & \\
\hline 1 (Constant) & 89.506 & 7.483 & & 11.960 & 0.001 \\
Age & 1.163 & 1.510 & 0.056 & 0.771 & 0.442 \\
Sex & 2.988 & 2.133 & 0.104 & 1.401 & 0.163 \\
Marital Status & 0777 & 0867 & 0.065 & 0.897 & 0.371 \\
Education & -0.292 & 0.801 & -0.030 & -0.364 & 0.716 \\
Occupation & -1.334 & 0.956 & -0.119 & -1.396 & 0.164 \\
Religious aff. & 0.751 & 1.319 & 0.043 & 0.569 & 0.570 \\
Duration of & 0.257 & 0.457 & 0.041 & 0.563 & 0.574 \\
Diabetes & & & & & \\
Monthly income & -0.531 & 0.466 & -0.089 & -1.140 & 0.256 \\
\hline
\end{tabular}

\subsection{Difference Between the Selected Hospitals and Self-Management Practices}

From Table 4, there were significant differences between means of the District Hospitals in terms of Self-Management Practices $(p=0.014)$. Hence, a Post Hoc tests was conducted to find out which pairs of means are statistically different. Mean difference between the management of diabetes patients receiving care at Wa regional hospital and those receiving care at Lawra district hospital was 8.86635 as indicated on Table 5. This implied those diabetes patients who received care at the Wa regional hospital managed themselves better than diabetes patient who receive care at Lawra district hospital. This could be as a result of patients at Wa regional hospital receiving proper education as compared to those at Lawra district hospital.

Table 4. Anova.

\begin{tabular}{llllll}
\hline Group & $\begin{array}{l}\text { Sum of } \\
\text { Squares }\end{array}$ & Df & $\begin{array}{l}\text { Mean } \\
\text { Square }\end{array}$ & F & $\begin{array}{l}\text { P } \\
\text { value. }\end{array}$ \\
\hline Between Groups & 1512.206 & 2 & 756.103 & 4.344 & 0.014 \\
Within Groups & 34466.550 & 198 & 174.073 & & \\
Total & 35978.756 & 200 & & & \\
\hline
\end{tabular}

Table 5. Multiple comparison.

\begin{tabular}{llllll}
\hline \multirow{2}{*}{ (J)District } & \multirow{2}{*}{ (I)District } & & $\begin{array}{l}\text { Mean } \\
\text { Difference (I-J) }\end{array}$ & $\begin{array}{l}\text { Std. } \\
\text { Error }\end{array}$ & Sig \\
\hline \multirow{2}{*}{} & \multirow{2}{*}{ Wa } & Lawra & 8.86635 & 3.01085 & 0.010 \\
& & Nandom & 1.46050 & 2.71472 & 0.853 \\
Tuckey & \multirow{2}{*}{ Lawra } & Wa & -8.86635 & 3.01085 & 0.010 \\
HSD & & Nandom & -7.40584 & 3.75890 & 0.122 \\
& \multirow{2}{*}{ Nandom } & Wa & -1.46050 & 2.71472 & 0.853 \\
& & Lawra & 7.40584 & 3.75890 & 0.122 \\
\hline
\end{tabular}

\section{Discussion}

The study explored the self-management practices of diabetes patients by asking questions in five main domains namely; medication, nutrition, monitoring, foot care and exercise.

It was revealed that majority of the participants adhered correctly to their medication regimen as found among other study participants $[15,16]$. The finding however contradicted with a research conducted at Korle-bu Teaching Hospital in 
Ghana in which smaller number of study participants adhered correctly to their medication regimen [17]. In this study most of the respondents asserted they had never missed a single dose of their medication over the past week which was similar to findings by other authors [16]. Also most of them agreed they were taking their medication for life since the disease could not be cured. Similar findings were observed elsewhere when respondents stated they were taking their diabetic drugs for life with the same reasons as above [16]. Majority of the participants followed instructions about their drugs strictly, and this was similar to the finding of other authors [18].

In all, participants of this study adhered to proper selfmanagement practices concerning their medications. This showed that participants demonstrated excellent practice in this domain. Though diabetes drugs were not affordable, participants still tried to adhere to proper medication practices. This could be as a result of their high knowledge on the importance of medications in managing their disease.

Most participants of the study ate less/no white bread, less fatty food including meat and reduced their intake of sugar and sweets. Elsewhere, lesser percentage of participants were found practicing these similar activities [19]. Majority of the study participants ate frequently but in smaller portion. Many ate more fruits and vegetables and drank more soup. This was in affirmation to other authors where majority of their study participants asserted to the above statements in attempt to control diabetes [19, 20]. Also majority of the study participants had never eaten forbidden food neither drank alcoholic beverages. There were similar observations where forbidden foods and alcohol intake were also not taken by the participants [20]. In a nutshell, the study participants of this study have demonstrated excellent practices on self-management activities on nutrition. This could be as a result of the presence of nutritionist in all the various facilities who took part in the education of the patients.

A few of the study participants also monitored their own blood glucose level as against what was found by Dunning et al where majority of the study participants monitored their own blood glucose level with their personal glucose meter [21]. Having a few of the participants of this study monitor their blood glucose level could be linked to their low financial status since some of them were not on salary and those on salary received monthly income less than GHC200.00. However, findings by other researchers showed high use of personal glucose meter unlike others who also registered fewer percentages [20, 22, 23]. Again a few of them monitored their blood glucose level more than once weekly which was similar to other findings [24]. The common practice among most of the participants is monitoring their blood glucose level only on their clinic days which was once every week. It could be that the hospitals often get short of glucometer strips from time to time and also the cost associated with testing discouraged the people from testing their glucose level.

Majority of the study participants regularly examined their feet for abnormalities which was contrary to other findings with similar practice of foot care [23]. The differences could be inadequate knowledge among the participants of this study on how to examine ones feet. Also few of the study participants cut their nails by the help of others with the reason of avoiding injury and also used closed foot wear for protection. However, those who cut their own nails stated they were being careful and put on closed foot wear to protect their feet [15]. Participants who cut their nails by themselves thought that they were more careful than others as opposed to participants that sought the help of others. Majority of the respondents used socks with rubber material and a few of them changed their socks or wore new ones every day. This could lead to foot problems among the study participants unlike other studies where majority of them had used cotton socks and changed them every day because of their level of knowledge [15].

Exercise was prioritized among the participants of this study as a way of managing their diabetes as compared to fewer participants of other studies [22]. Inadequate information on how exercise helps in the control of diabetes was given as a reason for fewer number involved in exercising [20].

It was evident from the study that none of the demographic factors of diabetes had influence on their self-management practices which is similar to the findings of other authors [15]. The finding is however contrary to that noted elsewhere when there exist a correlation between age and regular selfcare [25]. Older patients took better care of themselves than younger ones. [26]. However, the study findings conforms to that there was no association between the sex of the study participants and their self-care practices [15].

Though other demographic factors did not show any association with self-management practices, some studies established some relations [25, 27-29]. The study revealed that there was a statistically significant difference in selfmanagement practices of diabetes patients who received care at Wa and Lawra. The patients who received care at Wa regional hospital were better off regarding self-management practices because of the availability of better facilities and educational programs as compared to patients who received care at Lawra district hospital.

\section{Conclusions}

Most diabetes patients in the Upper West Region adhered to correct self-management practices on medication, nutrition and exercise. However, they needed to improve upon monitoring of blood sugar level and foot care. Also demographic factors of the participants of this study did not have influence on self-management practice.

Funding: no funding sources.

Conflict of interest: non declared.

Ethical approval: ethical approval for the study was sought from the Institutional Review Board of the University of Cape Coast with ID. No UCCIRB/CHAS/2015/42. 


\section{References}

[1] Shafer, K. N. (2000). Medical Surgical Nursing. United States of America: Mosby Company.

[2] Clavell, C. M. (2005). Mayo Clinic on Managing Diabetes. New York. Kensington Publishing Corporation.

[3] Iwueze, J. O. (2007). Managing your Diabetes: Assessment and Management of Patients with Diabetes Mellitus. Owerri. Skill mark Media Ltd.

[4] World Health Organization (WHO) (2011). World Health Organization Global Status Report on Non Communicable Diseases 2010. Geneva.

[5] Kyrou, I., \& Kumar, S. (2010). Weight management in overweight and obese patients with type 2 diabetes mellitus. The British Journal of Diabetes\& Vascular Disease, 10(6).

[6] World Health Organization (2006). Diabetes Mellitus. Epidemiology Statistics 3(1): 652-660.

[7] Tan, A. S., Yong, L. S., Wan, S., \& Wong, M. L. (2007). Patient education in the management of diabetes mellitus. Singapore Medical Journal, 38 (4), 156-60.

[8] Urhobo National Association of North America (2004). UNANA Home Projects: Report regarding the2004 Diabetes and High Blood Pressure Screening. Delta. In Uchenna1, V. O., Ijeoma1, O. E., Peace1, N. I. \& Ngozi, J. K. (2009). Knowledge of diabetes management and control by diabetic patients at Federal Medical Center Umuahia Abia State, Nigeria. International Journal of Medicine and Medical Sciences, 1(9), 353-358.

[9] Massi-Benedetti, M., \& CODE-2 Advisory Board (2002). The cost of diabetes Type II in Europe: the CODE 2 Study. Diabetologia 45: S1-4.

[10] International Diabetes Federation (IDF) (2013). DIABETES ATLAS, 6THedition.

[11] World Health Organization (WHO) (2014). Non Communicable Disease (NCD) Country Profiles-Ghana retrieved from http://www.who.int/nmh/ countries/gha.

[12] Ministry of Health (MOH) (2013). The Ghana Health Sector 2013 Programme of work. Count down to 2015; working together to achieve MDGs $4 \& 5$.

[13] Kpekura, S., Ninnoni J. P. K., \& Nuvor, S. V. (2018). Knowledge and attitude of patients with diabetes in government hospitals in the Upper West Region of Ghana, Int. J Community Med Public Health, 5(9). 3788-95.

[14] Mupepi, C. S.; Sampselle, M. C. \& Johnson, R. B. T. (2011). Knowledge, attitudes, and demographic factors influencing cervical cancer screening behavior of Zimbabwean women, Journal of Women's Health, 20 (6).

[15] Abu-Qamar, Z. M. (2014). Knowledge and practice of foot self-care among Jordanians with diabetes: An interview-based survey study. Journal of wound care, 2 3(5).
[16] Raithatha J. S., Shankar, U. S. \& Dinesh, K. (2014). Self-Care Practices among Diabetic Patients in Anand District of Gujarat. International Scholarly Research Notices, 2014 (2014), 1-6.

[17] Bruce, S. P., Acheampong, F., \&Kretchy, I. (2015). Adherence to oral anti-diabetic drugs among patients attending a Ghanaian teaching hospital. Pharmacy Practice, 13(1), 533.

[18] Jackson, I. L., Adibe, M. O., Okonta, M. J., \&Ukwe, C. V. (2014). Knowledge of self-care among type 2 diabetes patients in two states of Nigeria. Pharmacy Practice, 12(3):404.

[19] Shultz, A. J., Corbett, F. C., \& Allen, B. C. (2009). Slavic Women's Understanding of Diabetes Dietary SelfManagement and Reported Dietary Behaviors. Journal of Immigrant Minority Health, 11, 400-405.

[20] Garcia, A. G. J., Rocha, S. L. A., Lopez, I., Baerd, D. R., Dressler, W., \& Weller, C. S. (2007). Diabetes is my companion": Lifestyle and self-management among good and poor control Mexican diabetic patients. Social Science \& Medicine 64, 2223-2235.

[21] Dunning, T., \& Manias, E. (2005). Medication Knowledge and Self-Management by People with Type 2 Diabetes. Australian Journal of Advanced Nursing, 23(1).

[22] Phillips, C. K., Mashigeb, P. K., \& Clarke-Farrc, C. P. (2012). Knowledge of diabetes mellitus in privately-funded diabetic patients attending a rural optometric practice in Malmesbury South Africa. South African Optometrist, 71(2), 70-77.

[23] Arden, A. R J. G., Paz-Pacheco, E., Jimeno, A. C., LantionAng, L. F., Paterno, E., \& Juban, N. (2010). Knowledge, attitudes and practices of persons with type 2 diabetes in a rural community: Phase I of the community-based Diabetes Self-Management Education (DSME) Program in San Juan, Batangas, Philippines. Elsevier Ireland Ltd, 1 60-1 66.

[24] Chen, A., Huang, Z., Wan, X., Deng, W., Wu, J., Li, L., Cai, Q., Xiao, H., \&Li, Y., (2012). Attitudes toward Diabetes Affect Maintenance of Drug-Free Remission in Patients with Newly Diagnosed Type 2 Diabetes after Short-Term Continuous Subcutaneous Insulin Infusion Treatment. Diabetes Care, 35(1), 474-481.

[25] Abrahim, M. (2011). A Systematic Literature Review on Factors Contributing to Self-Care among Type 2 Diabetes Mellitus Patients. Linnaeus University, School of Health and Caring Sciences.

[26] Shiu, Y. T. A. (2007). National Standards for Diabetes SelfManagement Education. Diabetes Care, 30 (11).

[27] Akotey A. A. E. (2012). Barriers To Glycaemic Control among Diabetes Patients at the Korle-Bu Teaching Hospital, University of Ghana retrieved from http://ugspace.ug.edu.gh.

[28] Shrivastava, S. R., Shrivastava, P. S., \& Ramasamy, J. (2013). Role of self-care in management of diabetes mellitus. Journal of Diabetes \& Metabolic Disorders, 12(1), 14.

[29] Pender, J. N. (2011). Health Promotion Model Manual. Deep blue. Retrieved from https://deepblue.lib.umich.edu/bitstre. 